Kai Mückenberger

UDK 902.01(48+430)

Niedersächsisches Institut für historische

904"652"(430)

Küstenforschung, Wilhelmshaven Germany

Original research article

kaimuecke@hotmail.com

Received: June 24, 2010

Accepted: August 13, 2010

\title{
ASPECTS OF CENTRALITY IN THE REGION OF THE LOWER HUNTE RIVER IN THE ROMAN IRON AGE
}

\begin{abstract}
The question of centrality in barbaricum during the Roman Iron Age was mostly connected to exploring of the so-called central places of non-agrarian character and strong indications of trade and traffic in south Scandinavia. The greatest number of them was discovered in the coastal area, connected to traffic routes along river valleys and the coast.

In the coastal part of northwestern Germany there were no such site which could be analogue to the ones mentioned above. A possible reason could be the structure of the terrain. Still, since metal-detectors are more and more used in German archaeology, the number of finds and their spreading area indicated the existence of some of the production centres. In this paper, the site Elfsleth-Hogenkamp, in the Weser valley in north-western Germany is described, which could represent an example of such a site.

Finds gained in such a way include more than 60 fibulas, over 160 Roman coins made of copper alloy and silver, but also finds of Roman import made of copper alloy and numerous fragments of Roman pottery. This indicates that the site of Elsfleth-Hogenkamp can be considered a Roman Iron Age settlement with strong indications connected to trade and specialized crafts, which probably gained on importance due to its geographic position.
\end{abstract}

Key words: Roman Iron Age, Hunte, Elfsleth-Hogenkamp, centrality

\section{INTRODUCTION}

For the Roman Iron Age period the question of centrality in the barbaricum seems so far to have been dominated by research on so called central places in southern Scandinavia with a nonagrarian character and strong indications towards trade and traffic (summarizing Böhme 2001). The majority of them have been found in a maritime context with access to supra-regional traffic routes along rivers and coastal lines which offered the possibility of ship landing and therefore the establishment of so-called landing places (Ulriksen 1994, 797; 1998). The well-known finding 
complex of Gudme/Lundeborg, Fyn DK, can be understood as a preliminary model for a central place where the evidence of functions like trade, traffic, craft activity and cult accumulate to what could be called a centre of power and wealth (Kromann et al. 1991, $144-161$ ).

Looking at the coastal area of northwestern Germany, comparable central sites have been missing so far. A likely reason for this might be seen in the structure of landscape which is mainly influenced by the given contrast between the clay district areas and the sandy glacial deposits of the so called Geest. However, since the use of metal detectors in German archaeology has become more common, the number and distribution of finds in certain places at least led to the evidence of so called productive sites, as we already know them from Scandinavia and Britain (e.g. Ulmschneider 2003; Watt 2006). The following example of Elsfleth-Hogenkamp, administrative district Wesermarsch, northwestern Germany, might be seen as an instance of such a site.

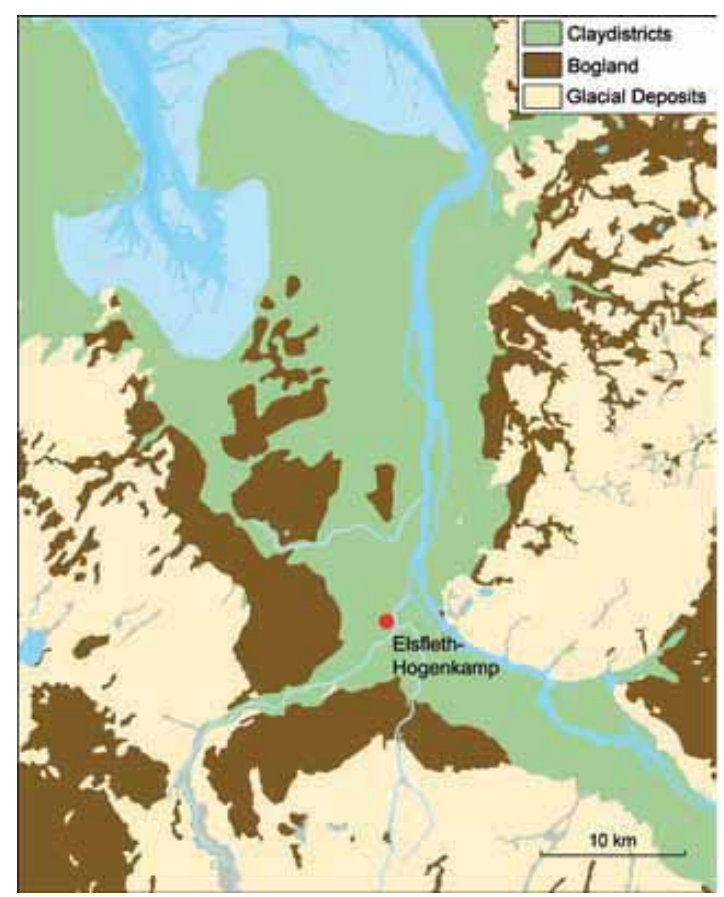

Fig. 1. Coastal area of north western Germany with the location of Elsfleth-Hogenkamp.

\section{THE LOCATION}

Situated in the clay district of the river Weser, the site can be found on the western bank of the Hunte river estuary, about three kilometres south from the contemporary centre of the village of Elsfleth (Fig. 1). Approximately $200 \mathrm{~m}$ behind the modern levee, a more or less round shaped acre of nearly 2.5 ha can be found which is slightly raised from the surrounding area (Fig. 2). Because of their higher altitude such riverbanks probably provided the best conditions for the establishment of rural settlements in the river clay districts (cf. Behre 2008, 32ff.). Nevertheless, recent drilling results could prove that the higher level of Elsfleth-Hogenkamp was caused by artificial advance which indicates a former dwelling mound (Mückenberger in prep.). Following the attribute of a higher ground level, the assumption could be made that the original settlement area might have had an extension towards the northeast, since a similar altitude can be recognized there as well.

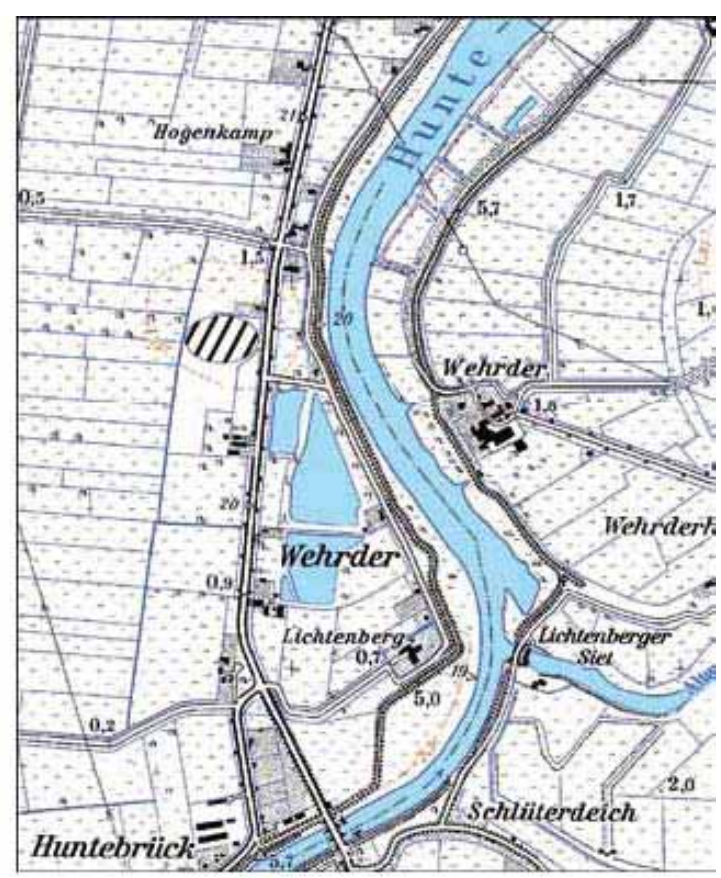

Fig. 2. Location of Elsfleth- Hogenkamp. Map basis: Topographical Map 1: 25 000. Copy permission by editor: LGN - Landesvermessung und Geobasisinformation Niedersachsen 
Today, this part is separated from the main site by a road while actual finds only emerged from the main area so far.

\section{RESEARCH HISTORY}

The first recording of Elsfleth-Hogenkamp goes back to the late $19^{\text {th }}$ century when large amounts of pottery still recognisable on its surface today led to a first note in scientific literature (Von Alten 1874). However, first trial trenches were not made until the 1930s (Schütte 1935; 1936; 1937). These investigations led to clear evidence of settlement activity mainly during the Roman period and early medieval times (summarizing Först 1991). An important aspect concerning the character of the settlement was discovered at the end of the 1980s in the find of a little ceramic boat model which represented the first archaeological indication of ships and traffic on the nearby riv- ers in the Roman period (Först 1989, $171-176$ esp. 174 f.; Ellmers 1999a 113 - 137 esp. 118). Recently excavated remains of a well preserved wooden wattle structure seem to lend further support to this point (Scheschkewitz 2006). However, the synopsis of these results did not suggest any special attitude of the settlement in comparison with other known stray find sites of the Roman period in the area, until it became the subject of constant surveying with a main focus on the use of metal detectors in the late 1990s. From then on, the density of metal finds increased dramatically.

\section{THE FINDS}

Amongst the finds over 60 brooches, more than 160 Roman copper alloy and silver coins, remains of Roman copper alloy import as well as numerous fragments of Roman pottery must be mentioned (Scheschkewitz 2006). While the col-

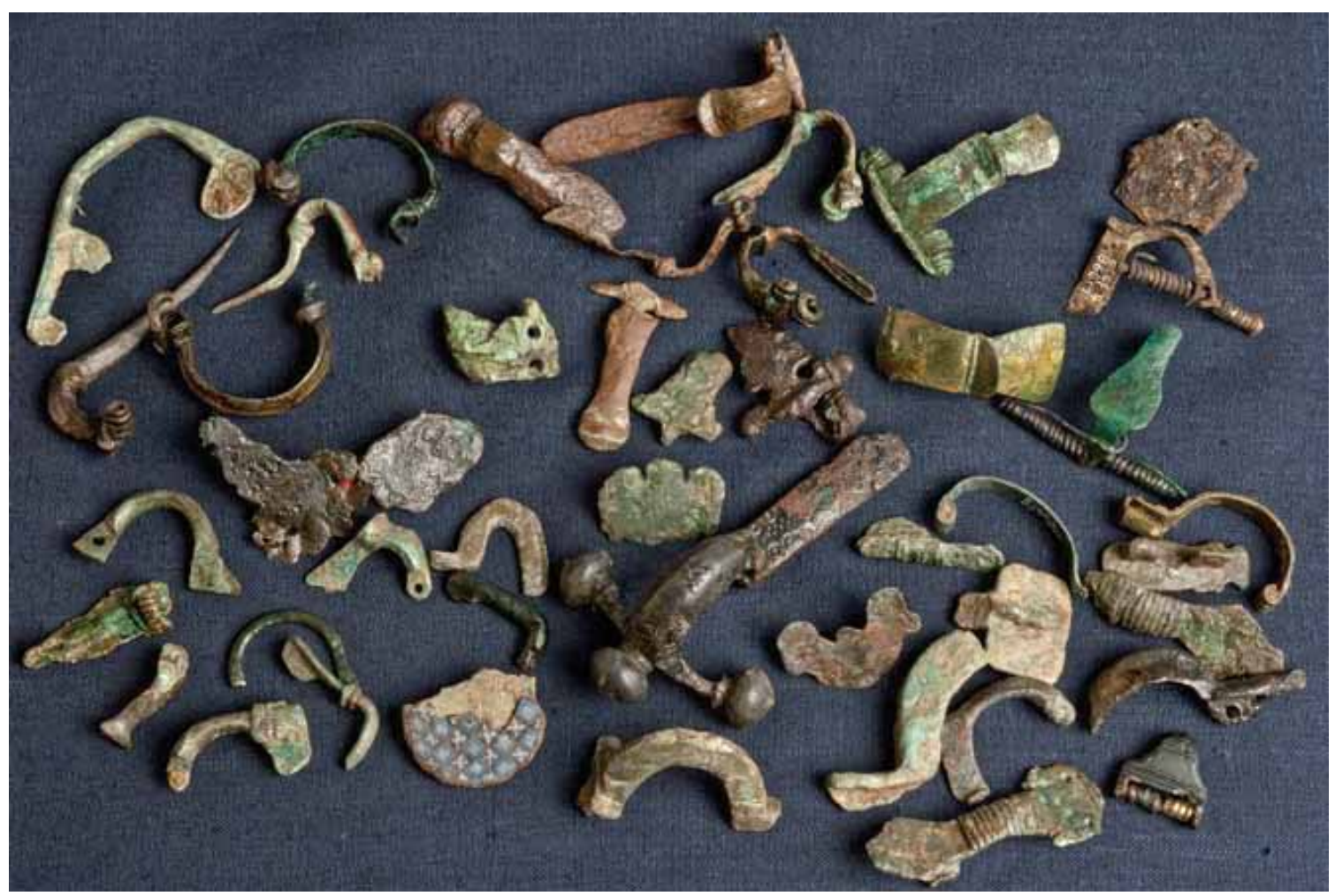

Fig. 3. Collection of brooches from Elsfleth-Hogenkamp ( $1^{\text {st }}-6^{\text {th }}$ century) (Foto: R. Kiepe NIhK). 


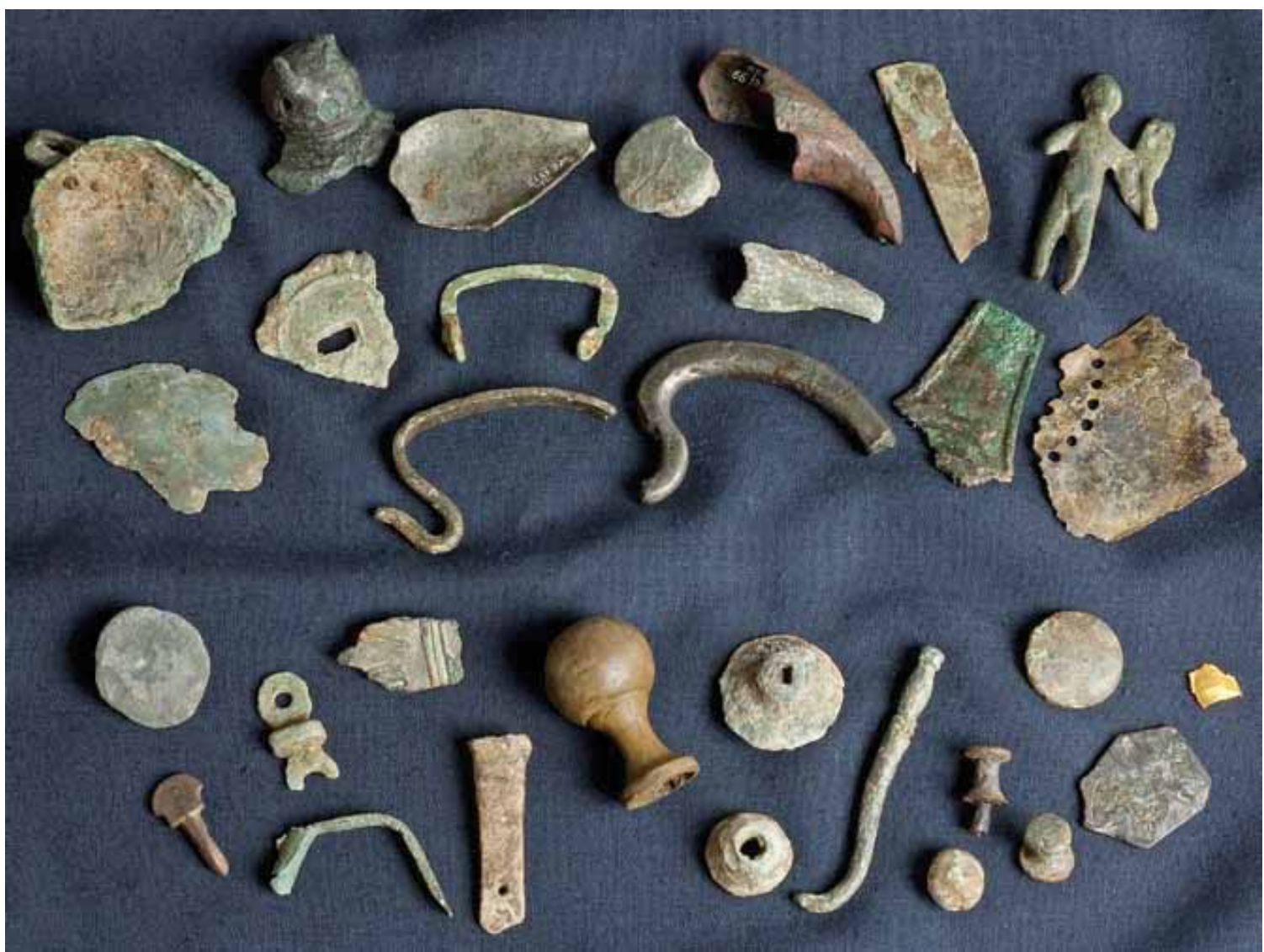

Fig. 4. Collection of nonferrous metal fragments from Elsfleth-Hogenkamp (Foto: R. Kiepe NIhK).

lection of brooches cannot be described in detail, a preliminary overview makes obvious that their dating covers the first five centuries A.D. without any large gaps (Fig. 3) (Scheschkewitz 2007, 170ff.).

In contrast to that, the analysis of the detected coins by Frank Berger, Historisches Museum Frankfurt am Main, led to the result that the majority spans the period from the $2^{\text {nd }}$ to the $4^{\text {th }}$ century A.D.. The preliminary results concerning the dating of the Roman pottery seem to suggest a similar time span as the coins (Günther Moosbauer, Osnabrück, pers. comm.). Additionally, hundreds of non-ferrous metal pieces have been collected from ploughing soil, mostly consisting of copper alloy. Amongst those remains, one can mainly distinguish between two groups of objects. The first consists of pieces that can be still allocated to their original function. Thus, several pieces of former military equipment such as horse-gear or late roman belt fittings and spurs can be recognized, while fingerings or pieces of vessels might count as objects of civil use (Fig. 4).

In contrast to that, the second group mostly consists of sheet metal fragments and melted copper alloy pieces, showing an indefinite form. Furthermore, a small amount of silver ingots together with a little piece of sheet gold indicate that the local metal handcraft comprised precious metal processing as well.

Due to the datable objects, this processing could be stretched over the same period as the brooches thus indicating that it was already established in the $1^{\text {st }}$ century A.D. Having said this, most of these $1^{\text {st }}$ century finds, for example eye-brooches or sesterces, seem to show traces of metal working. They make it necessary to discuss if they should rather be seen as aged scrap material which had arrived in Elsfleth together with the Roman pottery or the better preserved coins of 


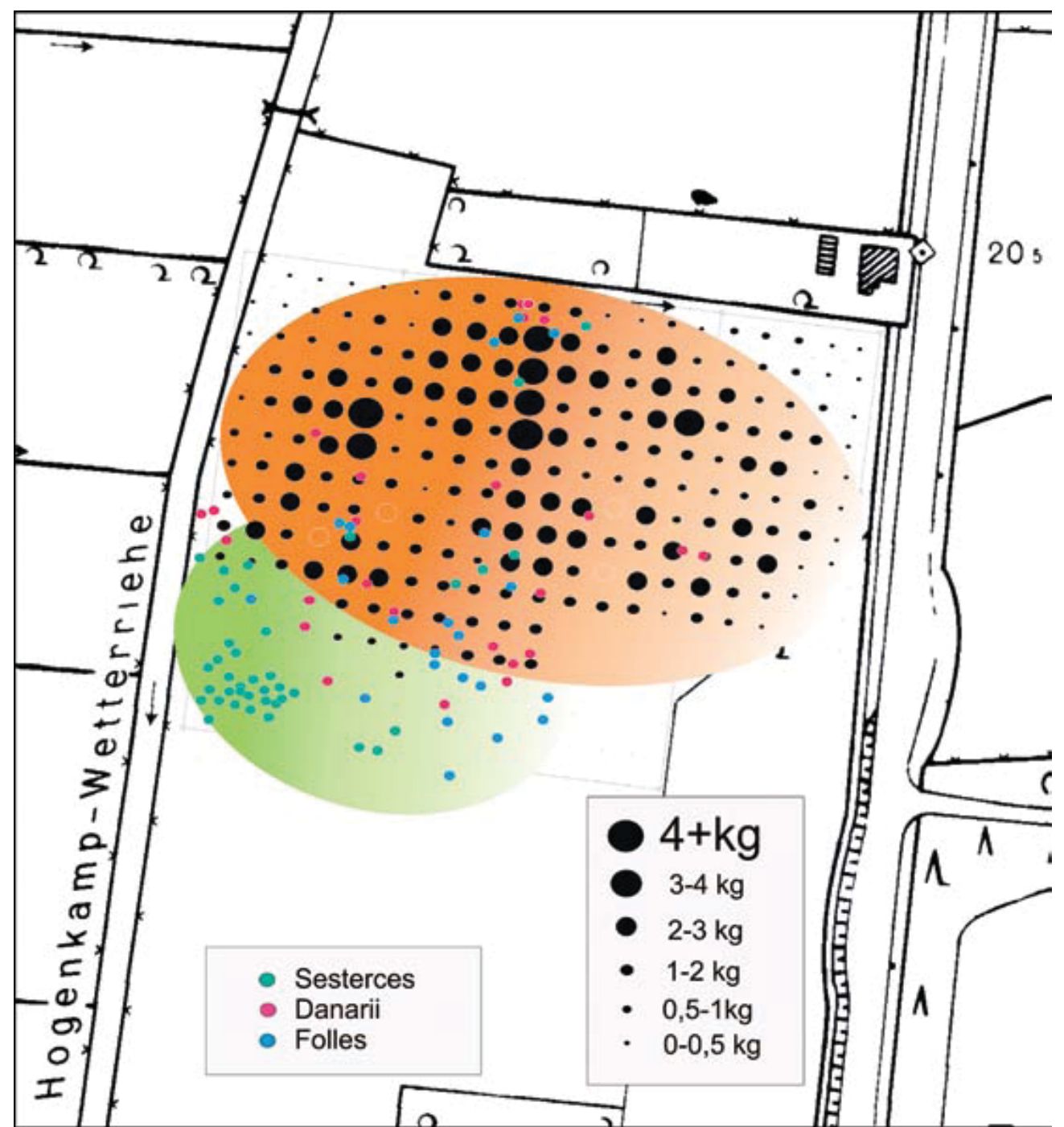

Fig. 5. Distribution of pottery and coins on the site. Green: Estimated metalworking area. Orange:

Settlement area.

the $2^{\text {nd }}$ and $3^{\text {rd }}$ century A.D. Finally, the material is completed by numerous settlement remains like local pottery, spindle whorls, loom weights and grindstones which indicate that rural settlement activity can also be expected on the site.

\section{AREAS OF DIFFERENT USE?}

To gain further information about the former extension of this settlement, recent surveys in 2008 focussed on the general distribution of finds over the area. In the course of the surveys, the remarkable amounts of nearly $300 \mathrm{~kg}$ of ceramic shards were collected from the ground surface, giving evidence for settlement continuity from the pre-Roman Iron Age up to the migration period (Mückenberger in prep.). It became apparent that the local pottery as well as the majority of silver coins was spread over the entire demanding area, showing several concentrations in the northern and western parts. In contrast to that, a southwestern area can be recognized where most of the copper alloy fragments appear together with the above-mentioned copper alloy coins of earlier dating (Fig. 5). From this it becomes obvious that one can distinguish between areas of different use within the former settlement. While the pot- 
tery and silver coins can probably be ascribed to intensive settlement and trading activity, the concentration of scrap material might show an area of former metal working.

\section{FUNCTION OF THE SETTLEMENT}

All in all it seems that Elsfleth-Hogenkamp can be during the first centuries A.D. (Ellmers 1999b) characterized as a Roman Iron Age settlement with Further support of this idea is given by the above strong indications of market- and specialized hand-mentioned wooden wattle remains and the little craft activity which probably gained significance from boat model which seem to point towards ship trafficits geographical situation. Indeed, the position of Els-as well. Recently found pieces of Roman millstones fleth-Hogenkamp provides excellent conditions forprobably suggest the same while their general distritrade and traffic as it offers access to different supra-bution mainly emphasizes the Weser-Hunte systemregional waterways like the Hunte and Weser rivers. as a main route for trade (Bischop 2001, 96f. Fig. 71). For that reason, it could be claimed that the majority Judging from this, it seems most likely that Elsflethof detected import reached Elsfleth by ship as is gen-Hogenkamp also represents a ship landing place of theerally assumed to have been the case for Roman goods. Roman period in the sense of Ulriksen $(1998,259)$ in northwestern Germany and southern Scandinavia.

\section{TRAFFIC ROUTES}

Concerning regional traffic with the hinterland, the west of Elsfleth (summarizing Hayen 1991, an additional aspect might be the evidence of the 109-122; Fansa/Schneider 1995, 5-42). Show-largest bog path of northwestern Germany

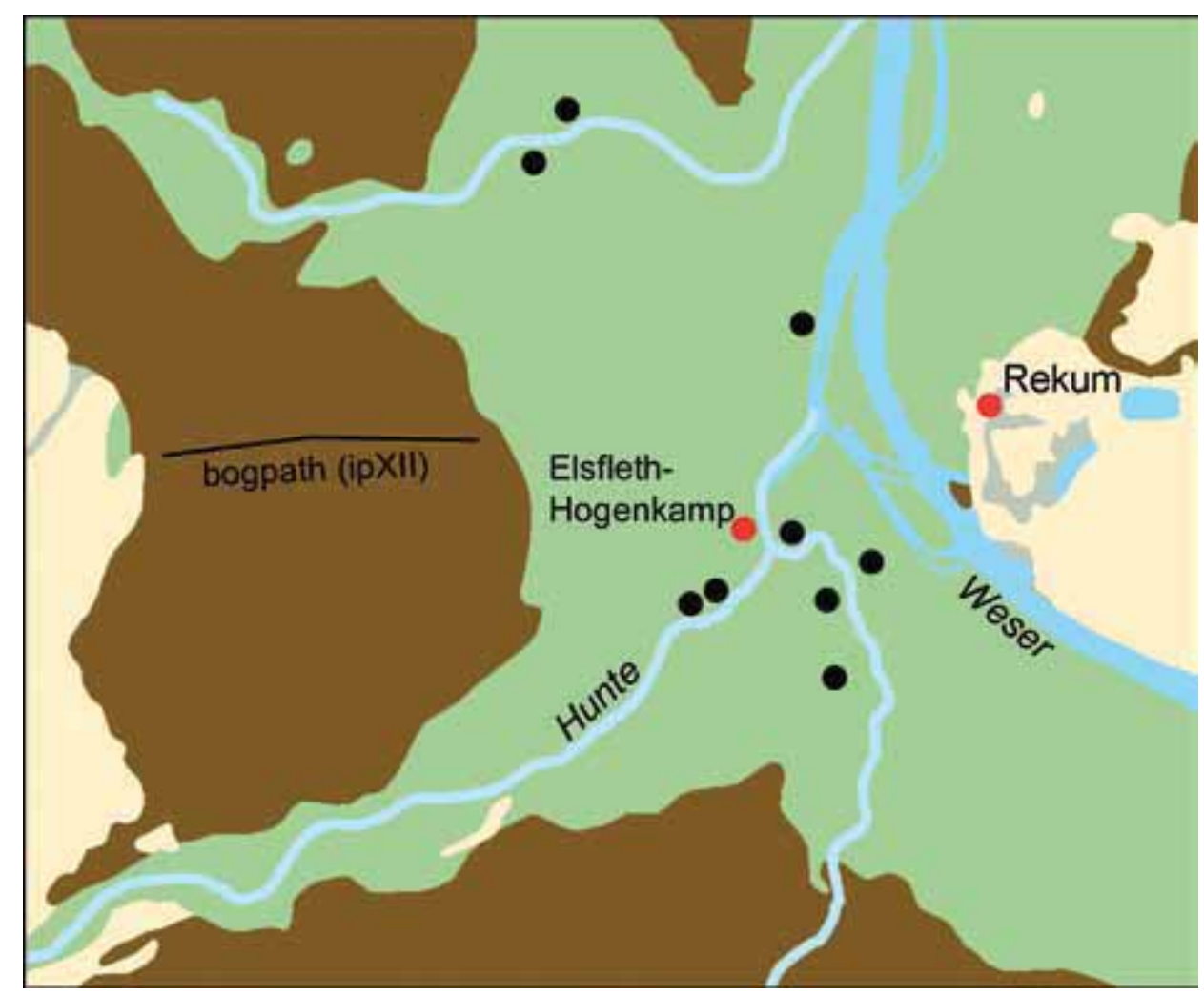

Fig. 6. Settlements of the Roman period and the location of bog path IP XII in the lower Hunte region (after Först 1991 with additions). 
(IP XII), ing a length of more than $6 \mathrm{~km}$ the western start-which can be found at a distance of about $5 \mathrm{~km}$ to ing point of the construction can be located at an exposed Geest ledge nearby Loyerberg, town Rast-dieval times (Krämer 1992, 110ff. Fig. 13). Meanede, administrative district Ammerland, while its while, several other bog paths can be recognized in eastern end can be found quite close to the church the area (Först 1991, 2ff. Fig. 1; Fansa / Schneiderof Bardenfleth/Eckfleth, administrative district 1995, Fig. 1), while their interpretation is still un-Wesermarsch (Fig. 6). Regarding its general align-clear. It has been a point of discussion whether they ment, it more or less seems to lead towards the site of can be generally assigned to an early colonization Elsfleth-Hogenkamp. However, the use of this struc-wave of the river clay districts (Metzler 1995, 60ff) ture in the Roman Iron Age seems quite doubtful at or if they have to be rather seen as ways of trade be-the moment as the preserved planks delivered quite tween land and waterways (Hayen 1989, 68ff.). Both early dendrochronological data from about $712 / 13$ possibilities for an interpretation of bog paths seem B.C.. On the one hand, this early dating seems to ex-reasonable. Nevertheless, their existence accounts clude the possibility for ongoing use in the Roman for a persisting need of man for dry and safe pas-period. On the other hand, the evidence of so called sage through the bogs in different periods. Together mussel tempered ware, which was found along the with supra-regional traffic routes such as rivers, they path in the course of an earlier excavation, might form a combined system of traffic routes of which count for a utilization that lasted up to early me-overland traffic was also a major part. Thus, the site of Elsfleth-Hogenkamp seems to be embedded into further explanation for the remarkable accumulaa system of trade and traffic routes of supra-regional tion of material from the site. and also regional relevance which can be seen as a Centrality in the Lower Hunte River Region Considering trade and traffic as two major functions of centrality, it should be investigated if further comparable sites exist in the local region which might show a similar set up and therefore deny the outstanding character of Elsfleth-Hogenkamp.

So far, about a dozen settlement places from the Roman period are known in the lower Hunte region (Fig. 6), but only few of them have been investigated by trial trenches (Först 1991, 94ff.). Therefore, it could be claimed that the lack of metal finds in other settlement sites was caused by the lack of a sufficient number of conducted surveys. In fact, most finds from those sites have not been published yet and thus cannot be used for any comparison. However, a small possibility for gaining an insight into the quantitative relations amongst those settlements might be given by considering the already published Roman coin finds which were obtained from nearly all known sites in the area (Berger et al. 2006, 226ff.). Firstly, their evidence confirms that earlier surveys were not only reduced to special places like ElsflethHogenkamp. Secondly, the different amounts of detected coins (e.g. max. six coins from Berne, administrative district Wesermarsch) clearly show the predominance of Elsfleth-Hogenkamp in comparison with the surrounding settlements. While those smaller numbers of coins can be seen as remains of daily life, the amount of about 160 roman coins in Elsfleth-Hogenkamp can only be explained with market activity which caused a series of subsequent losses over a longer period of time, comparable to the market place situation in Lundeborg, Fyn DK (Kromann 1993, 64ff.).

Due to the conditions in the river marshland it was recently assumed that nearly every settlement must have represented a landing place in the past because of the omnipresent tidal gullies in this area (Scheschkewitz 2008, in print). As a result it has to be questioned which circumstances ultimately led to the singular accumulation of material at Elsfleth-Hogenkamp. A possible explanation might be found in the short distance of only 
$5 \mathrm{~km}$ to the east on the other side of the river Weser to the contemporary village of Rekum (Fig. 6) where another settlement of the Roman period had been partly excavated several years before (Brandt 1984, 172-175). In contrast to the marshland settlement of Elsfleth, the site of Rekum was situated on the sandy soil of the nearby Geest where its position marks the most western point of the glacial deposits beyond the river Weser (Bischop 2000, 55ff. Fig. 79). Amongst the recovered features there a three aisled longhouse of $61 \mathrm{~m}$ length was excavated, representing one of the biggest examples in the whole area so far. Moreover, richly furnished graves within the settlement, dating to the Roman period as well as early medieval times, seem to prove that people at Rekum had comparable access to supra-regional trading goods like in the case of Elsfleth-Hogenkamp. In addition, the appearances of several horse and cattle burials in the environment seem to underline that a cultic significance of the place existed as well. In summary, the former settlement of Rekum provided many features that can be traced back to a place with certain central functions (Jöns 2009, in print). Thus, it might turn out that this settlement has to be seen in relation to the nearby site of Elsfleth-Hogenkamp which comprised different central functions in a close distance. Future research may deliver further indicators that, comparable to the preliminary model of Gudme/Lundeborg DK (Ulriksen 1994, 801-802), central functions were distributed to different places at one time in the lower Hunte region during the Roman period. Due to the special topographical conditions in the river clay district it seems to be appropriate to speak of a central region which, in contrast to southern Scandinavia, provided a different character.

\section{REFERENCES}

\section{Von Alten 1874}

F. von Alten, Mittheilungen über in friesischen Landen des Herzogthums Oldenburg vorkommende Alterthümer vorchristlicher Zeit. Archiv für Anthropologie 7, 1874, 35 - 41.

\section{Behre 2008}

K.-E. Behre, Landschaftsgeschichte Norddeutschlands. Umwelt und Siedlung von der Steinzeit bis zur Gegenwart (Neumünster 2008).

\section{Berger et al. 2006}

F. Berger / F.-W. Wulf, Die Fundmünzen der römischen Zeit in Niedersachsen und Bremen. Neufunde 1986 bis 2006. Nachtrag zu: Die Fundmünzen der römischen Zeit in Deutschland, Abteilung VII: Niedersachsen und Bremen. Bearbeitet von Frank Berger und Christian Stoess (Berlin 1988). Nachr. Niedersachsen Urgesch. Beiheft 12, Fundchronik 2005, 215 - 270.

\section{Bischop 2000}

D. Bischop, Siedler, Söldner und Piraten. Bremer Arch. Bl. Beiheft 2 (Bremen 2000).

\section{Bischop 2001}

D. Bischop, Die römische Kaiserzeit und frühe Völkerwanderungszeit zwischen Weser und Hunte. Eine archäologische Bestandsaufnahme des Landkreises Diepholz (Oldenburg 2001).

\section{Böhme 2001}

H. W. Böhme, Gedanken zu den frühen Marktund Handelsplätzen in Südskandinavien. In: E. Pohl / U. Recker / C. Theune (eds.), Archäologisches Zellwerk. Beiträge zur Kulturgeschichte in Europa und Asien. Interna- tionale Archäologie. Studia Honoria 16 [Festschr. H. Roth] (Rahden/Westfalen 2001) 483 - 498. 


\section{Brandt 1984}

K.-H. Brandt, Eine Siedlung der Römischen Eisenzeit auf dem Mühlenberg in Bremen-Rekum. Brem. Jahrb. 62, 1984, 172 - 174.

\section{Ellmers 1999a}

D. Ellmers, Wasserfahrzeuge und Ufermärkte der vorrömischen Eisenzeit im Wesergebiet. Studien zur Sachsenforschung 13, 1999, 113 - 137.

\section{Ellmers 1999b}

„Handelsschiffahrt“" In: RGA² 8, 1999, 595 - 609.

\section{Fansa / Schneider 1995}

M. Fansa / R. Schneider, Der Bohlenweg XII (ip) - Hünenbrücke - im Ipweger Moor und Grasmoor / Ldkr. Ammerland und Ldkr. Wesermarsch. Arch. Mitt. Nordwestdeutschland 18, 1995, 5- 42.

\section{Först 1989}

E. Först: Das Fragment eines spitzovalen Tongefäßes aus der Siedlung „Hogenkamp“, Gem. Stadt Elsfleth, Ldkr. Wesermarsch. Kunde N. F. 40, 1989, $171-176$.

\section{Först 1991}

E. Först, Zur Besiedlungsgeschichte der Flußmarsch im Kreis Wesermarsch. Veröff. Urgesch. Sammlung des Landesmuseums Hannover 37 (Hildesheim 1991).

\section{Hayen 1989}

H. Hayen, Bau und Funktion der hölzernen Moorwege. Einige Fakten und Folgerungen. In: Jankuhn et al. (eds.), Untersuchungen zu Handel und Verkehr der vor- und frühgeschichtlichen Zeit in Mittel- und Nordeuropa V. Der Verkehr. Verkehrswege, Verkehrsmittel, Organisation. Abhandlungen der Akademie der Wissenschaften in Göttingen, Philolog.-histor. K1.3. 180, 1989, 11 82 (Göttingen).

\section{Hayen 1991}

H. Hayen, Randmoore zwischen Marsch und Geest. Anmerkungen zu ihrer verkehrstechnischen Funktion. In: R. Krämer / M. Fansa (eds.), Bodenfunde aus der Wesermarsch. Arch. Mitt. aus Nordwestdeutschland. Beiheft 5, 109 - 122 (Oldenburg 1991).

\section{Iöns 2009 in print}

H. Jöns, Überlegungen zu Transport- und Kommunikationswegen des 1. Jahrtausends im nordwestdeutschen Nordseeküstengebiet. In: S. Brather (ed.), Frühes Mittelalter in Nordeuropa. Historia Archaeologia - RGA ${ }^{2}$ Ergänzungsband 70 [Festschrift H. Steuer] Berlin / New York 2009) $387-411$.

\section{Krämer 1992}

R. Krämer, Die Notgrabung am Bohlenweg XII (ip) aus dem Jahre 713 v. Chr. im Ipweger Moor, Ldkr. We sermarsch. Arch. Mitt. aus Nordwestdeutschland 15, 1992, $101-114$.

\section{Kromann et al. 1991}

A. Kromann / P. O. Nielsen / K. Randsborg / P. V. Petersen / P. O. Thomsen, Gudme og Lundeborg - et fynsk rigdomscenter i jernalderen. Nationalmuseets Arbejdsmark 1991, 144 - 161.

\section{Kromann 1993}

A. Kromann, Gudme and Lundeborg - the coins. In: P. O. Nielsen et al. (eds.), The archaeology of Gudme and Lundeborg. Arkæologiske Studier 10, 1993, $64-67$.

\section{Metzler 1995}

A. Metzler, Bericht über die Grabungen am Bohlenweg IP 12 durch das Institut für Denkmalpflege in 1989 und 1991. Arch. Mit. aus Nordwestdeutschland 18, 1995, $45-63$. 
Scheschkewitz 2006

J. Scheschkewitz, Ein Zentrum an der Huntemündung. Arch. Niedersachsen 9, 2006, $104-107$.

\section{Scheschkewitz 2007}

J. Scheschkewitz, Die Bleiobjekte und andere Begehungsfunde einer Marschensiedlung des 1. Jahrtausends n. Chr. bei Elsfleth, Kr. Wesermarsch. In: W. Melzer / T. Capelle (eds.), Bleibergbau und Bleiverarbeitung während der römischen Kaiserzeit im rechtsrheinischen Barbaricum. Soester Beiträge Arch. 8, 2007, 169 - 177.

\section{Scheschkewitz 2008}

J. Scheschkewitz, Transport on water - specialized landing-places in the coastal area of Northwestern Germany in the first millennium AD. In: M. Hardt / H. Jöns / S. Kleingärtner / B. Ludowici / J. Scheschkewitz (eds.), Trade and communication networks of the $1^{\text {st }}$ millennium AD in the northern part of Central Europe - central places, beach markets, landing places and trading centres [Workshop Bad Bederkesa 2008]. Neue Studien zur Sachsenforschung (Hannover in prep.)

\section{Schütte 1935}

H. Schütte, Eine erfolgreiche Wurtengrabung. Heimatkunde/Heimatschutz. Beilage der „Nachrichten für Stadt und Land“ Nr. 6 vom 1.9.1935.

\section{Schütte 1936}

H. Schütte, Landesverein Oldenburg für Heimatkunde und Heimatschutz. Jahresbericht 1936.

III. Geologie. Oldenburger Jahrb. 40, 1936, 223 -228 .

\section{Schütte 1937}

H. Schütte, Eine rein chaukische Siedlung an der Hunte. Heimatkunde/Heimatschutz. Beilage der „Nachrichten für Stadt und Land“ Nr. 10 vom 8.11.1937.

\section{Ulmschneider 2003}

K. Ulmschneider, Markets around the So-lent. In: T. Pestell / K. Ulmschneider (eds.), Markets in Early Medieval Europe. Trading and ,productive” sites (Macclesfield 2003) 650 - 850, 73 - 83.

\section{Ulriksen 1994}

J. Ulriksen, Danish sites and settlements with a maritime context, AD 200-1200. Antiquity 68, 1994, $797-811$.

\section{Ulriksen 1998}

J. Ulriksen, Anløbspladser. Besejling og bebyggelse i Danmark mellem 200 og 1100 e. Kr. (Roskilde 1998).

\section{Watt 2006}

M. Watt, Detector sites and settlement archaeology on Bornholm. A survey of ,productive sites" from the Iron Age and the Viking Age 1996-1999. Journ. of Danish Arch. 14, 139 - 167.

\section{NAPOMENA}

Ljubaznošću autora dopušteno nam je da objavimo rad koji je u originalu izašao u: Kiel Graduate School "Human Development in Landscapes" (eds.), Landscapes and Human Development: The Contribution of European Archaeology [Proceedings of the International Workshop "Socio-Environmental Dynamics over the Last 12,000 Years: The Creation of Landscapes (1st-4th April 2009)"] (Bonn 2010) $265-272$. 


\title{
ASPEKTI CENTRALNOSTI U OBLASTI DONJEG TOKA REKE HUNTE TOKOM RIMSKOG GVOZDENOG DOBA
}

\author{
Kai Mückenberger
}

\begin{abstract}
APSTRAKT
Pitanje centralnosti u barbarikumu tokom rimskog gvozdenog doba uglavnom se do sada odnosilo na istraživanja tzv. centralnih mesta neagrarnog karaktera i jakim indicijama prema trgovini i saobraćaju u južnoj Skandinaviji. Najveći broj njih otkriven je u primorju, sa pristupom međuregionalnim saobraćajnicama duž reka i priobalnog pojasa.

U priobalnom delu severozapadne Nemačke za sada nedostaju lokaliteti koji bi bili analogni. Moguć razlog za ovo bi se mogao tražiti u strukturi terena. Međutim, s obzirom na sve češ́́ upotrebu detektora metala u nemačkoj arheologiji, broj i rasprostranjenost nalaza na pojedinim mestima ukazali su na postojanje $i$ doveli do utvrđivanja tzv. proizvodnih centara. U radu je opisan lokalitet ElfslethHogenkamp, u dolini reke Weser, severozapadna Nemačka, koji se može smatrati primerom takvog naselja.

Nalazi dobijeni na ovaj način obuhvataju više od 60 fibula, preko 160 rimskih novčića od legure bakra i od srebra, a svakako treba spomenuti nalaze rimskog importa od legure bakra kao i brojne fragmente rimske keramike. To ukazuje na zaključak da se Elsfleth-Hogenkamp može okarakterisati kao rimsko gvozdenodopsko naselje sa jakim indicijama vezanim za trgovinu i specijalizovano zanatstvo, koji su verovatno dobili na značaju zbog svog geografskog položaja.
\end{abstract}

\section{Ključne reči: Rimsko gvozdfeno doba, Hunta, Elfsleth-Hogenkamp, centralnost}

\section{UVOD $^{1}$}

Pitanje centralnosti u barbarikumu tokom rimskog gvozdenog doba uglavnom se do sada odnosilo na istraživanja tzv. centralnih mesta neagrarnog karaktera sa jakim indicijama vezanim za trgovinu i saobraćaj u južnoj Skandinaviji (sažeto Böhme 2001). Najveći broj njih je otkriven u primorskom kontekstu, sa pristupom međuregionalnim saobraćajnim putevima duž reka i priobalnog pojasa, koji su brodovima pružali mogućnost ukotvljavanja i u tom smislu formiranja tzv.

1 Originalan tekst je na engleskom jeziku štampan u okviru publikacije „Landscapes and Human Development: The Contribution of European Archaeology“, proizašle iz kongresa „Socio-Environmental Dynamics over the last 12,000 Years: The Creation of Landscapes“, održane od 1. do 4. aprila 2009. u Kilu. Naslov originala glasi „Aspects of Centrality in the Region of the Lower Hunte River in the Roman Iron Age“, Bonn 2010, 265-272. lučkih naselja (Ulriksen 1994, 797; 1998). Dorbo poznat kompleks Gudme/Lundeborg, Fyn, Danska, može se smatrati preliminarnim modelom za centralno naselje u kojem su ustanovljene delatnosti kao trgovina, saobraćaj, zanatstvo i kult, a koje se ispoljavaju u nečemu što se može nazvati centralna moć i blagostanje (Kromann et al. 1991, 144-161).

Posmatrajući priobalni deo severozapadne Nemačke, ovde za sada nedostaju lokaliteti koji bi bili analogni. Moguć razlog za ovo bi se mogao tražiti u strukturi predela, uglavnom nastalog u kontrastu između glinovitih područja i peščanih glacijalnih naslaga tzv. Geest-a. Međutim, s obzirom da je upotreba detektora metala postala sve češća u nemačkoj arheologiji, broj i rasprostranjenost nalaza na pojedinim mestima ukazali su na postojanje tzv. proizvodnih centara. Utvrđe- 
no je postojanje proizvodnih centara kakvi su već poznati u Skandinaviji i Britaniji (npr. Ulmschneider 2003; Watt 2006). Naveden lokalitet Elfsleth-Hogenkamp-a, u administrativnoj oblasti Wesermarsch, severozapadna Nemačka, može se smatrati primerom takvog naselja.

\section{POLOŽAJ}

Lokalitet se nalazi na zapadnoj obali reke Hunte, u glinovitoj oblasti reke Weser, oko $3 \mathrm{~km}$ južno od centra sadašnjeg sela Elfsleth (sl. 1.). Oko 200 m iza sadašnjeg rukavca, nalazi se površina od 2,5 ha, manje ili više kružne osnove, blago izdignuta u odnosu na okolni teren (sl. 2.). S obzirom na veću visinu, moguće je da su takve obale pružale najbolje uslove za organizovanje ruralnih naselja u glinovitim oblastima oko reka (Behre 2008, 32 i dalje). Ipak, nedavno sondiranje terena je pokazalo da je viši nivo ElfslethHogenkamp-a zapravo rezultat veštačkog naslojavanja, što govori o ranijoj upotrebi ovog tela za nastanjivanje (Mückenberger, u pripremi). Prateći konfiguraciju izdignutog dela terena, može se pretpostaviti da se protezalo dalje u pravcu severoistoka, jer se na tom mestu takođe može uočiti izdignut teren.

Danas je ovaj deo od glavnog lokaliteta razdvojen putem. Nalazi su za sada i poznati samo sa glavnog područja.

\section{ISTORIJAT ISTRAŽIVNJA}

Prvi pomen Elsfleth-Hogenkamp-a je bio u 19. veku, kada su nalazi velike količine keramike doveli do toga da lokalitet prvi put bude zabeležen u naučnoj literaturi (Von Alten 1874). Ipak, prve probne sonde su postavljene tek tridesetih godina 20. veka (Schütte 1935; 1936; 1937). Ova istraživanja su dovela do otkrivanja jasnih tragova naseljavanja, uglavnom tokom rimskog perioda i ranog srednjeg veka (sažeto Först 1991). Važan aspekt, koji se odnosi na karakter naselja, otkriven je krajem osamdesetih godina 20. veka. Tada je otkriven model malog broda izređen u keramici, koji predstavlja prvu arheološku indiciju plovidbe i saobraćaja na obližnjim rekama tokom rimskog perioda (Först 1989, 171-176, naročito 174; Ellmers 1999a, 113-137, naročito 118). Nedavno otkriveni ostaci dobro očuvane strukture drvenog broda pružaju dalju potvrdu ove hipoteze (Scheschkewitz 2006). Međutim, sažimanjem ovih rezultata se nije došlo ni do kakvih zaključaka vezanih za tip naselja koje bi se moglo dovesti u vezu sa ostalim slučajnim nalazima sa ovog područja iz rimskog perioda. Tek je krajem 1990-tih ovo područje postalo predmet stalnog pretraživanja pomoću detektora metala. Od tada je količina metalnih nalaza drastično povećana.

\section{NALAZI}

Nalazi obuhvataju više od 60 fibula, preko 160 rimskih novčića od legure bakra i od srebra. Svakako, treba spomenuti nalaze rimskog importa od legure bakra kao i brojne fragmente rimske keramike (Scheschkewitz 2006). Zbirka fibula ovde ne može biti detaljno opisana, ali se preliminarno može reći da njihovo datovanje obuhvata period od prvih pet vekova naše ere, bez većih praznina (sl. 3.) (Scheschkewitz 2007, 170 i dalje).

Nasuprot tome, analiza novčića, koju je izvršio Frank Berger iz Istorijskog muzeja u Frankfurtu na Majni (Historisches Museum, Frankfurt am Main), pokazala je da većina pripada periodu od 2. do 4. veka naše ere. Preliminarni rezultati koji se odnose na rimsku keramiku ukazuju na isti vremenski period (Günther Moosbauer, Osnabrück). Dodatno su na stotine negvozdenih nalaza, većinom izrađenih od legure bakra, prikuljene tokom obrade zemlje. Među njima se uglavnom razlikuju dve vrste predmeta. Prva grupa obuhvata predmete kojima se još uvek može odrediti pri- 
marna funkcija. Tako se mogu prepoznati delovi vojničke opreme, npr. konjska oprema, kasnorimski pojasni delovi i mamuze, dok se prstenje i delovi posuda mogu smatrati predmetima civilne upotrebe (sl. 4.).

Nasuprot tome, druga grupa se uglavnom sastoji od fragmenata metalnog lima i komada topljene legure bakra nedefinisanog oblika. Dalje, otkriven je i mali broj srebrnih ingota, kao i mali komad zlatnog lima, koji ukazuju na postojanje lokalne metalurške radionice u kojoj su obrađivani i plemeniti metali.

Uzevši u obzir nalaze koje je bilo moguće datovati, aktivnost ove radionice se može datovati u isti period kao i fibule. Početak njene aktivnosti moguće je opredeliti na početak 1. veka n.e. Većina nalaza iz 1. veka n.e., npr. okaste fibule ili sesterciji, pokazuju tragove naknadne obrade metala. Zbog njih je neophodno razmotriti da li oni predstavljaju stari metal koji je u Elfsleth stigao sa rimskom keramikom ili pak bolje očuvane novčiće iz 2. i 3. veka n.e. Konačno, materijal upotpunjuju brojni ostaci iz naselja, kao lokalna keramika, pršljenci razboja, tegovi razboja i kamenovi graničnici, koji svi ukazuju da na ovom lokalitetu treba očekivati i naseobinsku aktivnost.

\section{PODRUČJA RAZLIČITE NAMENE?}

Da bi se dobile dalje informacije o nekadašnjem obimu naselja, iskopavanja iz 2008. su bila fokusirana na rasprostranjenost nalaza po celom terenu. Tokom istraživanja je sa površine prikupljena impozantna količina od skoro $300 \mathrm{~kg}$ keramičkih ulomaka, koji ukazuju na kontinuitet naseljavanja od prerimskog gvozdenog doba do seobe naroda (Mückenberger, u pripremi). Postalo je očigledno da su lokalna keramika i većina srebrnog novca bili rasprostranjeni po celoj istraživanoj površini, sa nekoliko koncentracija u severnom i zapadnom delu. Nasuprot tome, može se definisati jugozapadno područje, na kojem je nađena većina fragmenata od legure bakra zajedno sa ranije spomenutim starijim novčićima od legure bakra (sl. 5.). Usled ovoga, postalo je očigledno da se mogu razlikovati područja različite namene u okviru nekadašnjeg naselja. Dok se keramika i srebrni novčići verovatno mogu pripisati intenzivnom naseljavanju i trgovačkim aktivnostima, koncentracija sekundarnog materijala može da ukazuje na područje predviđeno za obradu metala.

\section{FUNKCIJA NASELJA}

Sve u svemu, čini se da se Elsfleth-Hogenkamp može okarakterisati kao rimsko gvozdenodopsko naselje, sa jakim indicijama vezanim za trgovinu i specijalizovano zanatstvo, koje je verovatno dobilo na značaju zbog svog geografskog položaja. Zaista, položaj Elsfleth-Hogenkamp-a daje odlične preduslove za trgovinu i saobraćaj, a takođe pruža mogućnost prilaza međuregionalnim plovnim putevima, kao što su reke Hunte i Weser. Iz ovog razloga, može se tvrditi da je većina importa do Elsfleth-a došla rečnim putem, što se inače, kada je rimska roba u pitanju, smatra čestim slučajem u severozapadnoj Nemačkoj i južnoj Skandinaviji tokom prvih vekova naše ere (Ellmers 1999b).

Još jednu dopunu ovoj ideji predstavljaju napred navedeni nalaz drvenog broda, kao i nalaz male makete broda, koji ukazuju i na brodski saobraćaj. Nedavno otkriveni komadi rimskog žrvnja možda ukazuju na isto. Opšta rasprostranjenost ovih nalaza uglavnom ističe plovni put Weser-Hunte kao glavnu trgovačku rutu (Bischop 2001, 96 i dalje, sl. 71). Sudeći po ovome, vrlo je moguće da Elsfleth-Hogenkamp takođe predstavlja luku u rimskom periodu, onako kako je tumači Ulriksen $(1998,259)$. 


\section{SAOBRAĆAJNI PRAVCI}

Što se tiče regionalnog saobraćaja sa zaleđem, to bi bio dodatni aspekt koji bi mogao predstavljati dokaz o postojanju najvećeg puta kroz močvaru u severozapadnoj Nemačkoj (IP XII), a koji se nalazi na rastojanju od oko $5 \mathrm{~km}$ zapadno od Elsfleth-a (sažeto Hayen 1991, 109-122; Fansa/Schneider 1995, 5-42). Put je dug preko $6 \mathrm{~km}$, a njegovo polažište na zapadu se može locirati na Geest platou u blizini Loyerberg-a, grad Rastede, administrativna oblast Ammerland. Njegov istočni kraj se nalazi sasvim blizu crkve Bardenfleth/ Eckfleth, administrativna oblast Wesermarsch (sl. 6). S obzirom na njegov opšti pravac, on manjeviše vodi ka lokalitetu Elsfleth-Hogenkamp. Međutim, njegova upotreba tokom rimskog gvozdenog doba dovedena je u sumnju u trenutku kada su očuvani balvani dali vrlo rano dendrohronološko datovanje od oko 712/713 g.p.n.e. Sa jedne strane, izgleda da ovako rano datovanje isključuje mogućnost kontinuirane upotrebe u rimskom periodu. Sa druge strane, otkriće tzv. keramike sa primesama tucane školjke, nalažene duž ovog puta tokom ranijih iskopavanja, može ukazivati na upotrebu koja je trajala sve do ranog srednjeg veka (Krämer 1992, 110 i dalje, sl. 13). U međuvremenu je otkriveno još nekoliko puteva kroz močvare u ovoj oblasti (Först 1991, 2 i dalje, sl. 1; Fansa/Schneider 1995, sl. 1), ali je njihova interpretacija još uvek nesigurna. Suština ove rasprave je da li ove puteve treba povezati sa ranim talasom naseljavanja rečnih gliništa (Metzler 1995, 60 ), ili ih pre treba smatrati putevima trgovine između zaleđa i rečnih dolina (Hayen 1989, 68 i dalje). Kada je u pitanju interpretacija puteva kroz močvare, obe mogućnosti imaju smisla. Njihovo postojanje, svakako, ukazuje na potrebu ljudi za suvim i bezbednim prolazima kroz močvare tokom različith perioda. Zajedno sa međuregionalnim saobraćajnim putevima, kao što su reke, oni čine kombinovan sistem saobraćajnica, čiji su glavni deo činili kopneni putevi. Na ovaj način se lokalitet Elsfleth-Hogenkamp uklapa u sistem trgovačkih i saobraćajnih puteva međuregionalnog i regionalnog značaja. To se može smatrati dodatnim objašnjenjem velike akumulacije materijala sa ovog lokaliteta.

\section{CENTRALNOST U OBLASTI DONJEG TOKA REKE HUNTE}

Ako se uzme da su trgovina i saobraćaj dve glavne funkcije centralnosti, trebalo bi utvrditi da li u ovoj oblasti postoje slični lokaliteti, koji bi pokazali sličnu strukturu i na taj način opovrgli stav da je lokalitet Elsfleth-Hogenkamp jedinstven.

Do sada je otkriveno desetak naselja iz rimskog perioda u oblasti donjeg toka Hunte (sl. 6), ali je samo nekolicina istražena pomoću probnih sondi (Först 1991, 94 i dalje). S toga se može tvrditi da je nedostatak metalnih nalaza sa ostalih naseobinskih nalazišta bio rezultat nedovoljnih istraživanja. Zapravo, većina nalaza sa ovih lokaliteta još nije publikovana i ne može biti korišćena za bilo kakvo poređenje. Ipak, uvid u kvantitativne odnose među ovim naseljima mogu predstavljati već objavljeni nalazi rimskog novca, koji postoje na gotovo svim lokalitetima u okruženju (Berger et al. 2006, 226 i dalje). Prvo, njihovo evidentiranje potvrđuje da prethodna istraživanja nisu bila usmerena samo na posebne lokalitete kao Elsfleth-Hogenkamp. Drugo, različite količine otkrivenog novca (npr. najviše šest novčića iz Berne-a, administrativna oblast Wesermarsch) jasno ukazuju na dominaciju Elfsleth-Hogenkamp-a u odnosu na ostala naselja u okruženju. Dok manje količine novčića mogu da se posmatraju kao pokazatelji svakodnevnog života, količina od gotovo 160 rimskih novčića iz Elfsleth-Hogenkamp-a, može se tumačiti samo kao trgovačka aktivnost, tokom koje je došlo do veće količine zagubljenih novčića u okviru dužeg vremenskog perioda, slično tržnici u Lundeborg-u, Fyn, Danska (Kromann 1993, 64 i dalje). 
Od nedavno se smatra da je, kada se u razmatranje uzmu uslovi u rečnim močvarama, u prošlosti, gotovo svako naselje moralo predstavljati i luku, s obzirom na sveprisutne tragove plavljenja u ovoj oblasti (Scheschkewitz 2008, u štampi). Dalje, treba ispitati koje su okolnosti zaista dovele do akumulacije materijala u ElfslethHogenkamp-u. Moguće objašnjenje bi bilo, malo rastojanje od samo $5 \mathrm{~km}$ ka istoku do druge obale reke Weser, kod savemenog sela Rekum (sl. 6), na kojem se nalazilo sledeće naselje iz rimskog perioda, a koje je nekoliko godina ranije delimično iskopavano (Brandt 1984, 172-175). Za razliku od močvarnog naselja Elfsleth, lokalitet Rekum se nalazi na peskovitom zemljištu obižnjeg Geest-a. Njegov položaj predstavlja najzapadniju tačku glacijalnih naslaga iza reke Weser (Bischop 2000, 55 i dalje, sl. 79). Među nalazima se izdvaja kuća dužine $61 \mathrm{~m}$ sa tri hodnika, koja predstavlja do sada najveću otkrivenu građevinu u ovoj oblasti. Osim toga, bogato opremljeni grobovi u okviru naselja, datovani u rimski period i period ranog srednjeg veka, ukazuju da su ljudi u Rekumu imali dodir sa međuregionalnom trgovinom baš kao što je to slučaj sa Elfsleth-Hogenkamp-om. Najzad, pojava nekolicine sahrana konja i stoke u okruženju, potvrđuje da je ovo mesto imalo i kultni značaj. Ukratko, nekadašnje naselje u Rekum-u je imalo mnogo odlika koje bi se mogle pripisati naselju sa izvesnom centralnom funkcijom (Jöns 2009, u štampi). Tako bi moglo da se pokaže da ovo naselje treba dovesti u vezu sa obližnjim lokalitetom Elfsleth-Hogenkamp, koje pak ima različite odlike centralnosti, a nalazi se u blizini. Dalja istraživnja bi, u poređenju sa primarnim modelom Gudme/ Lundeborg u Danskoj (Ulriksen 1994, 801-802), mogla da pokažu da su centralne funkcije bile raspoređene na različitim mestima $\mathrm{u}$ isto vreme $-\mathrm{u}$ donjem toku reke Hunte tokom rimskog peiroda. S obzirom na specifične topografske osobine u predelu rečnog gliništa, čini se da se može govoriti o centralnoj oblasti, koja je, nasuprot nalazištima iz južne Skandinavije, imala drugačiji karakter. 